\title{
The Impact of Perceived Risks and Perceived Benefits to Improve an Online Intention among Generation-Y in Malaysia
}

\author{
Trisna Tanadi ${ }^{1}$, Behrang Samadi ${ }^{1} \&$ Behrooz Gharleghi ${ }^{1}$ \\ ${ }^{1}$ Faculty of Business and Management, Asia Pacific University of Technology and Innovation (A.P.U), \\ Technology Park Malaysia, Bukit Jalil, Kuala Lumpur, Malaysia \\ Correspondence: Behrang Samadi, Faculty of Business and Management, Asia Pacific University of Technology \\ and Innovation (A.P.U), Technology Park Malaysia, Bukit Jalil, Kuala Lumpur 57000, Malaysia. E-mail: \\ behrang@apu.edu.my
}

Received: June 12, 2015 Accepted: July 1, 2015 Online Published: September 21, 2015

doi:10.5539/ass.v11n26p226

URL: http://dx.doi.org/10.5539/ass.v11n26p226

\begin{abstract}
This study examines the role of perceived risk and perceived benefit in improving the online intention among Generation-Y in Malaysia. The purpose of this study is to identify the valid measure of perceived risk and perceived benefit as the result with, associated with online intention among Gen-Y in Malaysia. In addition, this research proposes a new research framework on online intention by referring to numerous antecedent literatures of online intention. The conceptualization of consumer perceived risk and perceived benefits of this study provides empirical evidence in the study of online intention. Four types of risk, such as delivery risk, privacy risk, quality risk and time risk and four types of benefit such as shopping convenience, product selection, ease of shopping and shopping enjoyment were used to examine their impact toward online intention. In this study, a total of 200 questionnaires is distributed by the researcher which focus specifically on Gen-Y in Malaysia. Pearson Correlation and Multiple Regression analysis are employed in order to test the hypothesis and examine the relationship between the variables. The finding confirmed that all the dimensions of perceived risk and perceived benefit have played an important role in improving the intention of consumers to shop online. All the dimension of perceived risks has a significant negative relationship toward online intention and all the dimension of perceived benefits has a significant positive relationship toward online intention. In fact, this study provides useful assistance for online marketers to develop an effective marketing strategy in targeting Generation-Y consumers at the same time, they can get a broad overview about the risks and benefits of online intention where it leads to increase the involvement of Gen-Y in online shopping.
\end{abstract}

Keywords: perceived risk, perceived benefit, shopping convenience, product selection, ease of shopping and shopping enjoyment

\section{Introduction}

The Internet has become more well-known nowadays as the fast-paced growth of technology (Jamali et al., 2015; Tee et al., 2014). As the Internet has developed, people can use the Internet for any purposes. It is not only going to be used as a tool to do a networking medium, but also a transaction medium at a global market (Jamali et al., 2014; Yulihasri, Islam, \& Ku Daud, 2011). E-commerce gives advantages and chances for businesses to develop their businesses in the other part of the world and connect people in a borderless world. Consumers can do online shopping from anywhere at any time now since everything is at their fingertips. In fact, the development of the Internet has improved the popularity of online shopping. According to Ueno (2014), a report from JPMorgan in 2011, it was stated that in the year 2012 the total world revenue of e-commerce was approximately US $\$ 963$ billion whereby in Malaysia itself the growth of online shopping market in 2011 was RM842 million. They also predict that in 2016 the number of growth will even higher and it is going to exceed RM 1.9 billion. This shows there is a fast growth of e-commerce in Malaysia which has grown and expected to reach to an unbelievable growth in the future.

Although there is a significant growth of online shopping in the future, negative aspects and impacts of online shopping have become more related. Consumers are more concerned about their purchase decision. They will automatically think about risk and to which extend it is insecure. As Internet shopping is done through a virtual store, there is no human contact and consumers can't check the quality of a product, sometimes it makes 
consumers feel insecure and uncertainty about their purchase decision. They are worried about their pre-purchase experience as they afraid to face the unexpected loss from the purchase and product (Naiyi, 2004). In addition, based on the study done by Forsythe, et al. (2006), they found that the perceived benefit significantly affects the consumers' online intention. Perceived benefits are the results that related to the integration, which are valued by every individual. Wu (2003) said that perceived benefits were the total of online shopping advantages and satisfaction that meet their needs and wants. This is the perception of what customers gain after doing the online transaction.

In Malaysia, online shopping is a new technology breakthrough as it's still at the early stage of development and just started to attack the Malaysia retailing sector with online shopping services (Haque, Sadeghzadeh, \& Khatibi, 2006; Tee et al., 2013). In Malaysia, the number of Internet users is high, there are total 20,140,125 Internet users with the total population is 30,073,353. However, although Malaysia has high Internet access rate, only a small percentage of users have purchased online (Haque, Sadeghzadeh, \& Khatibi, 2006). According to Malaysian Communication and Multimedia Corporation (MCMC, 2005) as cited in Thaw \& Mahmood (2009), only 9.3\% of Internet users had made purchases through the Internet. The number of online shoppers has decreased as well in the year of 2002. As compared with the number of Malaysian shoppers shop online in the year of 2001 and 2002, online shopping rate in Malaysia has decreased from 4\% in 2001 to only 3\% in 2002 (Zulhuda, 2009). Moreover, in 2012, from the total 15 purposes of using the Internet, online shopping was in the $11^{\text {th }}$ position (Malaysian Digital Association, 2012). This shows there is a low percentage of consumers want to shop online.

On top of that National statistic also specified that $81 \%$ of consumers that browse the website for goods and services, they actually don't make an online shopping transaction. Malaysia is one of the countries that have high e-commerce fraud rates. It was ranked 7th out of 25 most fraudulent countries (Wong, 2013). Online shoppers feel unsecured with the transaction done over the Internet since nowadays cybercrime cases kept on increasing. Cybercrime activity like fraud can affect online shopping activity where it makes consumers afraid of giving their personal information online.

In addition, buying over the Internet also relates to consumers experiences and satisfaction that they perceive while shopping. Online shoppers can gain benefits as well from doing online shopping. Therefore, it is important to understand consumer perceptions toward online shopping as to improve and increase the online shopping intention in Malaysia. The strong of purchase intention will directly give impact to the purchase decision of the consumers.

\section{Literature Review}

\subsection{Perceived Risk}

Even though nowadays the number of online transaction is increasing, many people still hesitate and resist in using online transaction because they find several barriers in using it. According to Bauer (1960), online shopping involved risk since the purchasing action can create poor consequences which they were unconsciously approached to uncertainty. Besides, Bauer believed that perceived risk will give impact to a consumer purchase decision. Dowling \& Staelin (1994) stated that perceived risk was about the consumer perception toward the uncertainty of buying a product where it can make consumer become doubt in buying the product and lead for asking suggestion of the consequences of buying it. Stone \& Gronhaug (1993) believed that perceived risk is one of the most significant factors that influence consumer purchase intention. Comparing with traditional way of shopping, online shopping perceived to have higher risk. It's able to reduce the willingness of consumers to purchase good or service online (Barnes, 2007). Online shoppers are afraid to suffer losses by the time what they expect is not the same with the reality (Pavlou, 2003). Researchers have identified various risks associated with online intention such as delivery risk, privacy risk, quality risk and time risk. Based on the dimension of perceived risk, researcher proposed the following hypothesis:

$\mathrm{H}_{1}$ : There is a relationship between delivery risk and online intention

Delivery risk is the potential loss of delivery, which related to good lost, damaged and sent the product to the wrong place after customers do online transaction (Zhang, Tan, Xu, \& Tan, 2012). It also may include the risk of getting the product with a delay or not even receiving the product at all. The other delivery risk components that make people frightened to do online shopping is because first consumers worry that the firm will deliver the product late or not on time and it will take a long time because of several circumstances. Second is consumers fear that during transporting, the goods will be damaged cause of no proper packaging (Masoud, 2013). As an online retailer, it is important to ensure that the product isn't damaged or expired during the delivery. Then, guarantee an effective and accurate delivery service. If the merchant can provide accurate delivery service to its customer, it leads to increase the confidence level of placing the order and reduce the perceived risks of delivery 
(Tsai \& Yeh, 2010).

\section{$\mathrm{H}_{2}$ : There is a relationship between privacy risk and online intention}

The development of e-commerce has brought the issues and problems especially in privacy. According to George (2002), privacy risk can affect consumers' intention to make purchases over the Internet. Once consumers have faced unfavourable experience, then they might reluctant to purchase online again in the future. According to Featherman\& Pavlou (2003), privacy risk is about the potential loss of control over the customer personal data information. Lots of unauthorized people used the information without agreement and lead to misuse the information data.

A study done by Lenhart (2000), he found out that $8 \%$ of Internet users left the online world because of privacy and $54 \%$ of people have never gone online because they believed that the Internet is dangerous. Online shoppers are worried about the online payment security, reliability and privacy policy because during the payment process, consumers have to provide their personal and credit card information. Thus, privacy risk refers to the degree in which consumer may lose their personal information when doing an e-commerce transaction (Bhatnagar, Misra, \& Rao, 2000). In addition, another researcher defined privacy as the degree to which extend online shopping website is safe and protecting the privacy of consumer data (Kyauk \& Chaipoopirutana, 2014). Consumer online intention can increase if customers think the online retailer can protect their personal information securely. Hence, online companies that clearly communicate to consumers on how their private and transaction data are secured are more likely to benefit from increased consumer satisfaction (Ab Hamid et al., 2006).

\section{$\mathrm{H}_{3}$ : There is a relationship between quality risk and online intention}

In doing online shopping, shoppers rely on the limited information and picture that shown and provided on the website as product can't be touched (Jarvenpaa, Noam , \& Lauri, 1999). Quality risk is regarded on the option of the products which are out of order and the design isn't coming-up as what the customer expects. It also talks about the actual quality of the product which doesn't match with the product description. In other word, quality risk occurs when the products don't perform as what shoppers expected and shoppers fail to evaluate the quality of the product (Bhatnagar, Misra, \& Rao, 2000). This happens because before purchase the product, consumers have few chances to review the physical product quality.

Quality has become the most important point in consumers mind when making the online purchasing decision. As perceived quality is the most important element in making decision, it makes consumers comparing the quality of the product with the alternatives with regard to price among the same category (Jin \& Suh, 2005). In fact, the lower the perceived quality risk of the product, the high possibility of consumers wants to purchase online (Jaafar, Lalp, \& Naba, 2012). According to Yee \& San (2011), quality has a direct impact on customer purchase decision. So once a firm fails to deliver the product according to the standard of quality then it means the firm has failed in delivering the benefits (Zhang, Tan, Xu, \& Tan, 2012)

$\mathrm{H}_{4}$ : There is a relationship between time risk and online intention

According to Griffin \& Viehland (2010), time risk refers to the time needed by consumers to buy the product and time to obtain it. Then, according to Sim\& Su (2012), time risk relates to the potential loss of time, accessibility or effort associated with making a bad purchasing decision and when a product purchased needs to be fixed. In fact, while doing online shopping, consumers can waste their time in researching product information. This can also cause perceived time risk. Time risks may also include the inconvenience experience that customers face during making online transactions, navigating and submitting orders and delays in getting the products (Forsythe, Liu, Shannon, \& Gardner, 2006). Thus the time spent in waiting the transaction to complete consider as time risk also.

According to Broekhuizen \& Jager (2004), if consumer perceived risks are higher, then it leads them to spend more time and effort to make a decision. Based on Featherman \& Pavlou (2003), they defined time risk as the condition where consumers lose their time when making bad purchasing decision by wasting their time to research and make the purchase, then learn how to use the product again. Another researcher also stated that time risk is the potential loss of time related by making bad decisions by wasting time researching, shopping and replacing the unexpected goods.

\subsection{Perceived Benefit}

The term of online shopping depends on the consumers' perception over the activities that conducted through the Internet. Although the Internet provides some risks, in a different point of view Internet also gives big benefits to consumers. Customers would like to purchase online because they discover the advantages of using it. According to Forsythe, et al. (2006), perceived benefit replicates about what customers gain from online shopping. The 
perceived benefit of online shopping can be measured from the level of satisfaction over the product and the benefit of online shopping. According to Kim et,al (2008), perceived benefit is the belief of consumers to which extend they feel this online transaction is much better rather than other online transactions. Internet shopping benefit has significantly related with attitude toward online shopping and intention to shop online (Jarvenpaa \& Todd, 1996). In fact, the consumers' perceived benefits are the expansion of online shopping advantages or satisfaction that satisfies customers need and want (Delafrooz, Paim, \& Khatibi, 2011). Researchers have identified various benefits associated with online intention such as shopping convenience, product selection, ease of shopping and shopping enjoyment Based on the dimension of perceived benefit, researcher proposed the following hypothesis:

\section{$\mathrm{H}_{5}$ : There is a relationship between shopping convenience and online intention}

According to Forsythe, et al. (2006), shopping convenience is perceived of the ability to shop anytime from different place regardless the location and without visiting the store. Convenience is measured based on the duration of time consumed, location to shop and the process of purchasing. Comparing between the traditional way of buying with the practice of Internet shopping, online shopping gives more convenient to customers (Harn, Khatib, \& Ismai, 2006). Convenience here can be in the form of time, effort and stress. Shopping convenience was a strong motivator that influences the intention of potential internet shoppers to do online shopping (Koufaris, 2002).

With online shopping, consumers are allowed to browse and shop at any time convenient to them without having to worry about the shop service time, time zone and even a traffic jam (Juniwati, 2014). Customers can shop at any time as well without hassle and little interruption of other activities (Ko, Jung, Kim, \& Shim, 2004). They can access and purchase good wherever and whenever they want as the service is always available, 24 hour availability of online shopping (McKinney, 2004). Every step that we did during online shopping contributes to convenience of shopping. For instance, while browsing the products that we want is easy to find and search, it contributes to search convenience (Seiders, Berry, \& Gresham, 2000). Then, when the product is easy to obtain, it is possession convenience. While shopping can be done in quick time and the product can be delivered without delay, it is considered as time convenience (Kwek, Tan, \& Lau, 2010).

$\mathrm{H}_{6}$ : There is a relationship between product selection and online intention

Product selection is the availability of the numerous products and product information on the market as to support in helping customers to make decisions. Product selection offers customers the opportunity to compare, contrast and select the products that meet their needs and wants from multiple choices (Dillon \& Rief, 2004). Through online shopping, consumers are allowed to compare a large number of options and find substitute products under the same category (Rowley, 2000). The Internet allows merchants to offer a number of alternatives per category and look for unique products in the marketspace (Alba, et al., 1997). Based on Harn, et al., (2006), there is numerous product selections on the Internet due to there is no physical space limit. Thus, online consumers can discover a wide range of product available on the website that meets their needs. In fact, various product selections can increase online shopping intention and frequency (Luo, Ba, \& Zhang, 2012). Product differentiation can become another component that can increase shopper purchasing intention as well as motivate them to shop online.

$\mathrm{H}_{7}$ : There is a relationship between ease of shopping and online intention

According to Chahal (2013), ease of shopping relates to how easy or difficult its customers want to shop. Customers nowadays want to find everything that can make their life easier and more efficient. As stated by Forsythe, et al. (2006), ease of shopping refers to a condition where consumers avoid going to the store to shop. Customers can buy anything through an Internet gateway by just type-in what they want. Most of the online shopping sites, categorize their products into categories, subcategories and even sub-subcategories to help buyers in browsing products (Hunt, 1999). According to Shu-Hung \& Bayarsaikhan (2012), ease or comfort of shopping has a direct influence on online purchase intention.

Ease of shopping is defined as customer awareness that using the technology make them free from effort and difficulty (Ali Zaidi, Gondal, \& Yasmin, 2014). This can be considered as the benefit that is provided in the online shopping environment where it gives consumer shopping opportunity without physical and time controls (Cemberci, Civelek, \& Sozer, 2013). As the perceived ease of shopping is increased, attitude toward online shopping will become further positive.

$\mathrm{H}_{8}$ : There is a relationship between shopping enjoyment and online intention

Perceived enjoyment is a condition where consumers perceived an enjoyable online content service experience 
as well as performance consequences that can be anticipated (David, Bagozzi, \& Warshaw, 1989). According to Forsythe, et al. (2006), enjoyment refers to the fun or enjoyments that gain by customer in trying new experiences. According to Khoje et al., (2013) Beatty \& Ferrell (1998) stated that enjoyment was the pleasure gain from the process of online shopping. It reflects to the consumer perception toward the entertainment potential of online shopping (Monsuwe, Dellaert, \& Ruyter, 2004). Moreover, enjoyment is generated more from the fun and playfulness of online shopping experience rather than from the finishing point of shopping activity (Kwek, Tan, \& Lau, 2010). The researchers named Harn, et al., (2014) suggested that perceived enjoyment positively influence consumers' purchase intention.

As stated by Wolfinbatger \& Gilly (2001), in order to reach the level to which a website can lead to shopping enjoyment, the firm should design a website which is unique because researchers found out that once customers sees a unique website, there will be a big intention for them to buy, more positive mood and greater shopper satisfaction. It is also supported by Wen, et al., (2011) where he found out that website design and information provided on the website are the two main factors that help customers to increase the level of enjoyment. According to Koufaris (2002), shopping enjoyment has a significant impact toward an attitude and intention in online shopping. In addition, Jarvenpaa \& Todd (1996) stated that shopping enjoyment can have a significant impact on attitude, behaviour on the web and increase customer intention toward online shopping.

\section{Methodology}

\subsection{Participant Characteristic}

The age group among consumers has played a significant role in the market because it can help the marketers to segment and influence the buying behaviour. Different people with different age group have different purchasing behaviour. Here, the scope of the study is conducted to Generation-Y individuals in Malaysia. Gen-Y is the potential customers in the market. Due to the technology development and the increasing of Internet popularity, nowadays a lot of consumers, especially Gen-Y like to utilize Internet to do online shopping. Gen- $Y$ or young people are those individuals who was born in the range of 1977 to 1994 (Ruane \& Wallace, 2013) whereby it means in the year of 2014, their age are from 20 to 37 years old. Gen-Y are more active, comfortable and interested with new technology as the Internet can help users to observe pertaining to product information, service, payment process and so on (Wood, 2002). This group of people has high purchasing power and has the potential of earning greater income (Jariah, Husniyah, Laily, \& Britt, 2004)

\subsection{Sampling}

This study adopts a quantitative research approach. Looking into the sampling methodology, the total population of Gen-Y in Malaysia is 5,092,065 million whereby this number was considered as a big number of the sample group. In collecting the data about this research, a total of 200 questionnaire survey has been distributed to respondents through physical distribution and online survey. However, from 200 questionnaires distributed only 150 questionnaires were returned back successfully to the researcher. As a result, it gave a response rate of 75 percent. According to Sekaran (2003), 75 percent is considered sufficient and acceptable for statistical reliability.

\subsection{Measure}

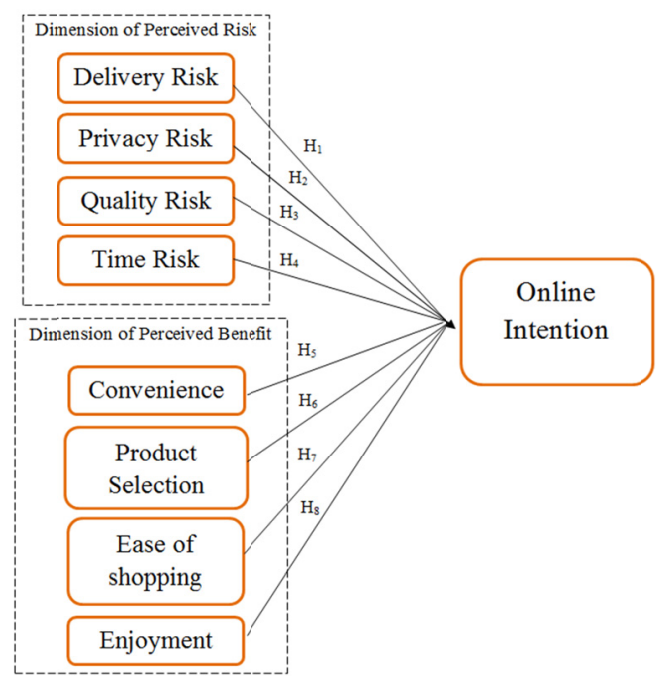

Figure 1. Theoretical framework 
In finding the outlier, this study employed normality, reliability and EFA for testing the goodness of the data. Then, Pearson Correlation and Multiple Regression test for testing the hypothesis and examine the relationship between the variable. Following figure shows the theoretical framework of the research.

\section{Empirical Results}

Table 1. Demographic analysis

\begin{tabular}{|c|c|c|}
\hline Variable and Component & Frequency & Percentage $(\%)$ \\
\hline \multicolumn{3}{|l|}{ Gender } \\
\hline Male & 55 & 36.7 \\
\hline Female & 95 & 63.3 \\
\hline \multicolumn{3}{|l|}{ Age } \\
\hline Below 18 & 2 & 1.3 \\
\hline $18-22$ & 122 & 81.3 \\
\hline $23-26$ & 24 & 16.0 \\
\hline $27-30$ & 2 & 1.3 \\
\hline \multicolumn{3}{|l|}{ Nationality } \\
\hline Malaysian & 68 & 45.3 \\
\hline Non-Malaysian & 82 & 54.7 \\
\hline \multicolumn{3}{|l|}{ Education } \\
\hline High School & 5 & 3.3 \\
\hline Institute Graduate (Diploma) & 9 & 6.0 \\
\hline Undergraduate (Degree) & 130 & 86.7 \\
\hline Postgraduate (Master) & 6 & 4.0 \\
\hline \multicolumn{3}{|l|}{ Ever Tried Online Shopping } \\
\hline Yes & 140 & 93.3 \\
\hline No & 10 & 6.7 \\
\hline \multicolumn{3}{|l|}{ Number of Times does Online Shopping } \\
\hline Never & 10 & 6.7 \\
\hline $1-4$ & 44 & 29.3 \\
\hline $5-9$ & 49 & 32.7 \\
\hline $10-15$ & 41 & 27.3 \\
\hline Other & 6 & 4 \\
\hline \multicolumn{3}{|l|}{ Frequency of doing online shopping } \\
\hline Never & 10 & 6.7 \\
\hline Once a week & 10 & 6.7 \\
\hline Weekly & 4 & 2.7 \\
\hline Monthly & 38 & 25.3 \\
\hline Occasionally & 88 & 58.7 \\
\hline
\end{tabular}

The table above shows the breakdown of the respondent's gender, age, nationality, education level, number of times doing online shopping and frequency of doing online shopping. Here, the questionnaires are distributed to different ranges of groups in order to have different point of view from different respondents. 


\subsection{Reliability Test}

Table 2. Cronbach Alpha test

\begin{tabular}{ccc}
\hline Construct & Number of Items & Cronbach Alpha Coefficient \\
\hline Delivery & 3 & 0.760 \\
Privacy & 4 & 0.794 \\
Quality & 5 & 0.778 \\
Time & 3 & 0.716 \\
Shopping convenience & 4 & 0.919 \\
Product Selection & 4 & 0.864 \\
Enjoyment & 4 & 0.801 \\
Ease of Shopping & 6 & 0.714 \\
Online Intention & 4 & 0.924 \\
\hline
\end{tabular}

Reliability test is a test that used to examine the internal consistency of the data. Normally, it uses Cronbach Alpha coefficient to determine the value. The Cronbach Alpha Coefficient has to be above or at 0.7 in order to get good internal consistency or reliable value. When the value is above 0.7 , it is considered as acceptable, while if the value is below than 0.7, it is considered to be poor (Pallant, 2013).

As we can see from the table above, the Cronbach Alpha for all 8 independent variable and 1 dependent variable is above 0.7 where this indicates there is a high internal consistency. In other word, all variables are reliable.

\subsection{Exploratory Factor Analysis (EFA)}

EFA is one of the analysis components that used to test the interrelationship of the variables. Two statistical measurements such as Bartlett and Kaiser-Meyer-Olkin (KMO) will be used to check the appropriateness of the factor analysis.

Table 3. EFA results

\begin{tabular}{ccccc}
\hline Construct & Approx. Chi Square & df & Sig. (p) & Kaise-Meyer-Olkin (KMO) \\
\hline Delivery Risk & 112.078 & 3 & 0.000 & 0.681 \\
Privacy Risk & 45.960 & 6 & 0.000 & 0.640 \\
Quality Risk & 183.708 & 10 & 0.000 & 0.817 \\
Time Risk & 353.004 & 3 & 0.000 & 0.633 \\
Shopping Convenience & 448.013 & 6 & 0.000 & 0.823 \\
Product Selection & 277.322 & 6 & 0.000 & 0.829 \\
Enjoyment & 181.973 & 6 & 0.000 & 0.789 \\
Ease of shopping & 297.298 & 15 & 0.000 & 0.705 \\
\hline
\end{tabular}

According to the table above, the KMO value of all constructs is 0.6 and above. Then, the Bartlett Test value, especially the sig. value is less than 0.05 . This indicates that the relationship among the variables is significant and factor analysis is acceptable. In fact, the value range for KMO is between 0 to 1 where 0.6 is the minimum value for a good factor analysis, whereas for Bartletts test, the sig (p) value has to be below 0.05 so that the factor analysis is considered appropriate (Pallant, 2013). Therefore, all the variables are appropriate as the $p$ value is less than 0.05 and $\mathrm{KMO}$ value above 0.6 .

\subsection{Pearson Correlation}

Pearson Correlation Coefficient is used to measure the correlation and the relationship between two variables. It also used to test the hypothesis. The aim of doing hypothesis testing is to reject the null hypothesis (Ho) and 
accept the alternative hypothesis. In fact, the null hypothesis is rejected when the degree of significant is less than 0.05 . If the significance of $p$ is less than 0.05 , then it indicates that there is significant correlation between independent and dependent variable. On the other hand, if the significance value is more than 0.05 , it means there is no significant correlation between the two variables. In this study, to interpret the correlation coefficient (r), the model proposed by Cohen will be used (Cohen, 1988). The $r$ value tells about the strength of the relationship and direction of the variables.

Table 4. Pearson correlation analysis

\begin{tabular}{cc}
\hline "r" value & Interpretation \\
\hline $\mathbf{0}<\mathbf{x}<\mathbf{0 . 3}$ & Weak correlation \\
$\mathbf{0 . 3}<\mathbf{x}<\mathbf{0 . 7}$ & Moderate correlation \\
$>\mathbf{0 . 7}$ & Strong correlation \\
\hline
\end{tabular}

Table 5. Pearson correlation results

\begin{tabular}{cccc}
\hline Construct & Online Intention & N & Sig. \\
\hline Delivery Risk & 0.166 & 150 & 0.042 \\
Privacy Risk & 0.166 & 150 & 0.042 \\
Quality Risk & 0.194 & 150 & 0.018 \\
Time Risk & 0.165 & 150 & 0.043 \\
Shopping Convenience & 0.440 & 150 & 0.000 \\
Product Selection & 0.513 & 150 & 0.000 \\
Enjoyment & 0.466 & 150 & 0.000 \\
Ease of shopping & 0.494 & 150 & 0.000 \\
\hline
\end{tabular}

The table above shows there is a relationship between the dependent variable and independent variables as follow:

- Correlation between delivery risk and online intention is a weak correlation because the $\mathrm{r}$ value is 0.166 .

- Correlation between privacy risk and online intention is a weak correlation because the $r$ value is 0.166 .

- Correlation between quality risk and online intention is a weak correlation because the $r$ value is 0.194 .

- Correlation between Time risk and online intention is a weak correlation because the $r$ value is 0.165 .

- Correlation between shopping convenience and online intention is a moderate correlation because the $r$ value is 0.440 .

- Correlation between product selection and online intention is a moderate correlation because the $r$ value is 0.513 .

- Correlation between enjoyment and online intention is a moderate correlation because the $r$ value is 0.466 .

- Correlation between ease of shopping and online intention is a moderate correlation because the $r$ value is 0.494 .

To proceed with hypothesis testing regression analysis is used as it appears in next section.

\subsection{Regression}

Regression analysis is used when independent variables and a dependent variable are correlated one another. In this study, all hypothesis obtained from the correlation analysis are accepted. Although, it is accepted, the researcher has to ensure there is an actual relationship between two variables, thus regression analysis will be prepared. Multiple regression will be conducted as we would like to predict the value of a variable from the value of two or more other variables (Abdulahi, Samadi, \& Gharleghi, 2014). 
Table 6. Model summary

\begin{tabular}{ccccc}
\hline Model & $\mathrm{R}$ & R Square & Adjusted R Square & Std. Error of the Estimate \\
\hline 1 & $.594^{\mathrm{a}}$ & .353 & .316 & .61982 \\
\hline
\end{tabular}

a. Predictors: (Constant), Ease, Quality, Delivery, Convenience, Time, Enjoyment, Privacy, Selection

Based on the table above, the value of R-square of the eight independent variables such as delivery, privacy, quality, time, shopping convenience, product selection, enjoyment, ease of shopping is 0.353 . The value of 0.353 indicates that the eight variables can explain $35.3 \%$ of the variation of the dependent variable which is online intention. On the other hand, the remaining $64.7 \%$ of the variation of the online intention isn't being explained in this research. In other words, there are other factors that can be used to determine the impact of perceived risks and perceived benefit to improve online intention among Gen-Y in Malaysia.

Table 7. ANOVA

\begin{tabular}{ccccccc}
\hline & Model & Sum of Squares & df & Mean Square & F & Sig. \\
\hline \multirow{4}{*}{1} & Regression & 29.574 & 8 & 3.697 & 9.622 & $.000^{\mathrm{b}}$ \\
& Residual & 54.170 & 141 & .384 & & \\
& Total & 83.743 & 149 & & & \\
\hline
\end{tabular}

a. Dependent Variable: Intention

b. Predictors: (Constant), Ease, Quality, Delivery, Convenience, Time, Enjoyment, Privacy, Selection

According to the table above, the significance value (sig) for the variety of independent variables and the dependent variable is less than 0.05 which is 0.000 . This indicates the relationship between independent variables (delivery, privacy, quality, time, shopping convenience, product selection, enjoyment, ease of shopping) and a dependent variable (online intention) of this research are significant. As a result, the overall regression model is considered to accurately predict the impact of perceived risks and perceived benefits toward online intention.

Table 8. Regression results

\begin{tabular}{ccccccc}
\hline \multirow{2}{*}{ Model } & \multicolumn{2}{c}{ Unstandardized Coefficients } & Standardized Coefficients & \multirow{2}{*}{ Sig. } \\
\cline { 2 - 5 } & $\mathrm{B}$ & Std. Error & Beta & & \\
\hline \multirow{4}{*}{ (Constant) } & 1.237 & .478 & & 2.591 & .011 \\
Delivery & -.036 & .015 & -.040 & 2.404 & .042 \\
Privacy & -.096 & .036 & -.062 & -2.617 & .044 \\
Quality & -.068 & .110 & -.057 & -.617 & .418 \\
Time & -.033 & .091 & -.032 & -.367 & .243 \\
Convenience & .107 & .100 & .110 & 1.069 & .101 \\
Selection & .243 & .102 & .245 & 2.384 & .047 \\
Enjoyment & .195 & .111 & .176 & 1.751 & .089 \\
Ease & .295 & .108 & .241 & 2.741 & .036 \\
\hline
\end{tabular}

a. Dependent Variable: Intention

From the result in coefficient table above, ease of shopping has the most significant relationship with online intention because the unstandardized coefficient of the ease of shopping $(\beta=0.295)$ is the highest among all the variables. In addition, the unstandardized coefficient of shopping convenience $(\beta=0.107)$, product selection $(\beta=$ $0.243)$ and shopping enjoyment $(\beta=0.195)$ have a positive relationship with online intention, whereby this 
means when the online intention is increased, then the shopping convenience, product selection and shopping enjoyment benefit are increased as well. On the other hand, delivery $(\beta=-0.036)$, privacy $(\beta=-0.096)$, quality $(\beta=-0.068)$ and time $(\beta=-0.033)$ have a negative relationship with online intention. This induces when the online intention increase, the delivery, privacy, quality and time risks of online shopper decrease.

\section{Hypothesis Testing}

Following table provides the result of hypothesis testing. Based on the regression results, hypotheses number 1, 2, 6 , and 8 are accepted and the rest are rejected. This is obtained from the significancy of the variables in regression table.

\begin{tabular}{cccc}
\hline Hypothesis & Variables & Coefficient value & Final decision \\
\hline $\mathrm{H}_{1}$ & Delivery Risk & $\beta=-0.036$ & Accepted \\
$\mathrm{H}_{2}$ & Privacy Risk & $\beta=-0.096$ & Accepted \\
$\mathrm{H}_{3}$ & Quality Risk & $\beta=-0.068$ & Rejected \\
$\mathrm{H}_{4}$ & Time Risk & $\beta=-0.033$ & Rejected \\
$\mathrm{H}_{5}$ & Shopping Convenience & $\beta=0.107$ & Rejected \\
$\mathrm{H}_{6}$ & Product Selection & $\beta=0.243$ & Accepted \\
$\mathrm{H}_{7}$ & Enjoyment & $\beta=0.295$ & Rejected \\
$\mathrm{H}_{8}$ & Ease of Shopping & $\beta=0.195$ & Accepted \\
\hline
\end{tabular}

\section{Conclusion}

In a nutshell, based on the correlation result, all the variables such as delivery risk, privacy risk, quality risk, time risk, shopping convenience, product selection, ease of shopping and shopping enjoyment are correlated with improving Generation-Y online intention. In increasing consumer online intention, consumers perceived greater benefit and less risk. First of all in the dimension of perceived benefit: shopping convenience, product selection, ease of shopping and shopping enjoyment have a positive relationship toward online intention. In fact, marketers have to consider these factors if they would like to increase their sales through online channel. Through online purchasing, customers can access many brands and retailers from everywhere and they can get numerous selections of products available on the Internet.

Furthermore, in the dimension of perceived risk, quality, privacy, delivery and time risks are shown negative relationship toward online intention. Most of the respondents still perceived that online shopping is risky, this indicate as the quality, privacy, delivery and time risk increase, the online intention of Generation-Y is going to be deteriorated. In other word, if customer perceived online shopping is risky then they will reduce their intention to shop online. Customers worry to purchase goods online because they are afraid the items aren't delivered after the payment, their personal information will be leaked out to other companies that can affect their privacy and the product isn't delivered as what they expect. Therefore, firms have to improve their security requirements so that it can mitigate the risk perceived by the consumer. Among all the variables of perceived benefit and perceived risk, only four variables are found to be significant namely, delivery risk, privacy risk, product selection, and ease of shopping.

\section{References}

Abdulahi, A., Samadi, B., \& Gharleghi, B. (2014). A Study on the Negative Effects of Social Networking Sites Such as Facebook among. International Journal of Business and Social Science, 5(10), 133-145. Retrieved from http://www.researchgate.net/profile/Behrang_Samadi/publication/272490714_A_Study_on_the_Negat ive_Effects_of_Social_Networking_Sites_Such_as_Facebook_among_Asia_Pacific_University_Scholars_i n_Malaysia/links/54e61 d8c0cf277664ff2f764.pdf

Alba, J., Lynch, J., Weitz, B., Janiszewski, C., Lutz, R., \& Sawyer, A., et al. (1997). Interactive Home Shopping: Consumer, Retailer, and Manufacturer Incentives to Participate in Electronic Marketplaces. Journal of Marketing, 61(3), 38-53. http://dx.doi.org/10.2307/1251788.

Ali Zaidi, S. D., Gondal, B. J., \& Yasmin, A. (2014). Antecedents of Online Shopping Intention: A Study held in Pakistan. Journal of Sociological Research, 5(1), 231-247. http://dx.doi.org/10.5296/jsr.v5i1.6564 
Barnes, S. J. (2007). Segmenting cyberspace: a customer typology for the internet. European Journal of Marketing, 41(1/2), 71-93. http://dx.doi.org/10.1108/03090560710718120

Bhatnagar, A., Misra, S., \& Rao, H. R. (2000). On risk, convenience, and Internet shopping behavior. Communications of the ACM, 43(11), 98-105. http://dx.doi.org/10.1145/353360.353371

Cemberci, M., Civelek, M. E., \& Sozer, E. G. (2013). The determinants of intention to shop online and effects of brand equity on e-store patronage. Journal of Global Strategic Management, 13, 125-145. Retrieved from http://www.isma.info/uploads/files/121-the-determinants-of-intention-to-shop-online-and-effects-of-brand-e quity-on-e-store-patronage.pdf

Cohen, J. (1988). Statistical Power Analysis for the Behavioral Sciences (2nd ed.). New Jersey: Lawrence Erlbaum.

David, F. D., Bagozzi, R. P., \& Warshaw, P. R. (1989). Perceived enjoyment is a condition where consumers perceived an enjoyable online service experience as well as performance consequences that can be anticipated. Management Science, 35(8), 982-1003.

Delafrooz, N., Paim, L. H., \& Khatibi, A. (2011). Understanding consumer's internet purchase intention in Malaysia. Journal of Business Management, 5(3), 2837-2846. http://dx.doi.org/10.5897/AJBM10.1266

Dillon, T. W., \& Rief, H. L. (2004). Factors Influencing Consumers' E-Commerce Commodity Purchases. Information Technology, Learning, and Performance Journal, 22(2). Retrieved from http://www.ijhssnet.com/journals/Vol_2_No_4_Special_Issue_February_2012/27.pdf

Forsythe, S., Liu, C., Shannon, D., \& Gardner, L. C. (2006). Development of a scale to measure the perceived benefits and risk of online shopping. Journal of Interactive Marketing, 20(2), 55-75. http://dx.doi.org/10.1002/dir.20061

Haque, A., Sadeghzadeh, J., \& Khatibi, A. (2006). Identifying Potentiality Online Sales In Malaysia: A Study On Customer Relationships Online Shopping. The journal of applied business research, 22(4), 119-130. Retrieved from http://connection.ebscohost.com/c/articles/23147858/identifying-potentiality-online-salesmalaysia-study-customer-relationships-online-shopping

Harn, A. C., Khatib, A., \& Ismai, H. b. (2006). E-Commerce: A Study on Online Shopping in Malaysia. Journal of Social Science, 13(3), 231-242. Retrieved from http://citeseerx.ist.psu.edu/viewdoc/download?doi=10.1. $1.516 .6458 \&$ rep $=$ rep $1 \&$ type $=$ pdf

Jaafar, S. N., Lalp, P. E., \& Naba, M. M. (2012). Consumers' Perceptions, Attitudes and Purchase Intention towards Private Label Food Products in Malaysia. Asian Journal of Business and Management Sciences, 2(8), 73-90. Retrieved from http://www.ajbms.org/articlepdf/8ajbms2012282721.pdf

Jamali, S. K., Samadi, B., \& Marthandan, G. (2014). Prioritizing Electronic Commerce Technologies in Iranian Family SMEs. Interdisciplinary Journal of Contemporary Research in Business, 6(2), 148-180. Retrieved from http://www.researchgate.net/publication/265209012_Prioritizing_Electronic_Commerce_Technologie s_in_Iranian_Family_SMEs

Jamali, S. K., Marthandan, G., Khazaei, M., Samadi, B., \& Fie, D. Y. G. (2015). Conceptualizing Model of Factors Influencing Electronic Commerce Adoption in Iranian Family SMEs. Asian Social Science, 11(10), 256. http://dx.doi.org/10.5539/ass.v11n10p256

Jariah, M., Husniyah, A. R., Laily, P., \& Britt, S. (2004). Financial behavior and problems among university students: need for financial education. Journal of Personal Finance, 3(1), 82-96. Retrieved from http://www.researchgate.net/publication/228404924_Financial_behavior_and_problems_among_university _students_Need_for_financial_education

Jarvenpaa, S. L., \& Todd, P. A. (1996). Consumer reactions to electronic shopping on the world wide web. International Journal of Electronic Commerce, 1(2), 59-88. Retrieved from http://dl.acm.org/citation.cfm?id=1189803\&picked=prox\&cfid=536841293\&cftoken=41744171

Jarvenpaa, S. L., Noam, T., \& Lauri, S. (1999). Consumer Trust in an Internet Store: A Cross-Cultural Validation. Journal of Computer-Mediated Communication, 5(2). http://dx.doi.org/10.1111/j.1083-6101.1999.tb00337.x

Jin, B., \& Suh, Y. G. (2005). Integrating effect of consumer perception factors in predicting private brand purchase in a Korean discount store context. Journal of Consumer Marketing, 22(2), 62-71. http://dx.doi.org/10.1108/07363760510589226

Juniwati. (2014). Influence of Perceived Usefulness, Ease of Use, Risk on Attitude and Intention to Shop Online. 
European Journal of Business and Management, 6(27), 218-228.

Khojeh, E., Mohseni, S., \& Samadi, B. (2013). Enhancing Customer Satisfaction Among SMEs through Web Technology. Research Notes in Information Science, 11, 13-28. Retrieved from http://www.globalcis.org/ rnis/global/paper_detail.html?jname=RNIS\&q=119

Ko, H., Jung, J., Kim, J. Y., \& Shim, S. W. (2004). Cross-cultural differences in perceived risk of online. Journal of Interactive Advertising, 4(2), 20-29. http://dx.doi.org/10.1080/15252019.2004.10722084

Koufaris, M. (2002). Applying the Technology Acceptance Model and Flow Theory to Online Consumer Behavior. Journal of Information Systems Research, 13(2), 205-223. http://dx.doi.org/10.1287/isre. 13.2.205.83

Kwek, C. L., Tan, H. P., \& Lau, T. C. (2010). Investigating the Shopping Orientations on Online Purchase Intention in the e-Commerce Environment: A Malaysian Study. Journal of Internet Banking and Commerce, 15(2). Retrieved from http:/www.arraydev.com/commerce/JIBC/2010-08/Kwek.pdf

Kyauk, S. T., \& Chaipoopirutana, S. (2014). Factors Influencing Repurchase Intention:A Case Study of Xyz.Com Online Shopping Website in Myanmar. International Conference on Trends in Economics, Humanities and Management, 177-180. Retrieved from http://icehm.org/siteadmin/upload/3251ED 0814092.pdf

Luo, J., Ba, S., \& Zhang, H. (2012). The effectiveness of online shopping characteristics and well-designed websites on satisfaction. MIS Quaterly, 36(4), 1131-1144. Retrieved from http://www.misq.org/skin/ frontend/default/misq/pdf/appendices/2012/V36I4Appendices/LuoBaZhangAppendices.pdf

Malaysian Digital Association. (2012). Malaysian Website Rankings for February 2012. Retrieved October 20, 2014, from http://www.digital.org.my/pdf/MDA-EM_WebsiteRanking_Report_Feb12.pdf

Masoud, E. Y. (2013). The Effect of Perceived Risk on Online Shopping in Jordan. European Journal of Business and Management, 5(6), 76-87. Retrieved from http://www.iiste.org/Journals/index.php/ EJBM/article/view/4689/4768

McKinney, L. N. (2004). Creating a Satisfying Internet Shopping Experience via Atmospheric Variables. International Journal of Consumer Studies, 28(3), 268-283. http://dx.doi.org/10.1111/j.1470-6431.2004. 00368.x

Monsuwe, T. P., Dellaert, B. G., \& Ruyter, K. d. (2004). What drives consumers to shop online? A literature review. International Journal of Service Industry Management, 15(1), $102-121$. http://dx.doi.org/10.1108/09564230410523358

Naiyi, Y. (2004). Dimensions of Consumer's Perceived Risk in Online Shopping. Journal of Electronic Science and Technology of China, 2(3), 177-182. Retrieved from http://www.journal.uestc.edu.cn/archives/2004/ 3/2/177-18286892.pdf

Pallant, J. (2013). SPSS survival manual: a step by step guide to data analysis using IBM SPSS / (5th ed.). England: McGraw Hill. http://dx.doi.org/10.1080/00396338.2013.784467

Pavlou, P. A. (2003). Consumer Acceptance of Electronic Commerce: Integrating Trust and Risk with the Technology Acceptance Model. International Journal of Electronic Commerce, 7(3), 101-134. http://dx.doi.org/ 10.1080/10864415.2003.11044275

Rowley, J. (2000). Product Search in E-Shopping: A review and research propositions. Journal of Consumer Marketing, 17(1), 20-25. http://dx.doi.org/10.1108/07363760010309528

Ruane, L., \& Wallace, E. (2013). Generation Y females online:insights from brand narratives. Qualitative Market Research: An International Journal, 16(3), 316. http://dx.doi.org/10.1108/13522751311326125

Seiders, K., Berry, L. L., \& Gresham, L. G. (April 15, 2000). Attention, Retailers! How Convenient Is Your Convenience Strategy? Sloan Management Review.

Tee P. Kiong, Gharleghi, B., Chan Yin F, B., and Lim M. K. 2014. Electronic Ticketing in Airline Industries among Malaysians; the Determinants. International Journal of Business and Social Science, 5(9), 168-174. Retrieved from http://www.ijbssnet.com/journals/Vol_5_No_9_August_2014/20.pdf

Tee, P. K., Gharleghi, B., \& Chan, B. Y. F. (2013). Malaysian Young Consumer Preferences in Choosing International Fashion Brand. Journal of Human and Social Science Research, 1(1), 31-38. Retrieved from http://www.oricpub.com/HSSR-1-1-14-1.pdf 
Tsai, Y. C., \& Yeh, J. C. (2010). Perceived risk of information security and privacy in online shopping: A study of environmentally sustainable products. Journal of Business Management, 4(18), 4057-4066. Retrieved from http://www.academicjournals.org/app/webroot/article/article1380549606_Tsai\%20and\%20Yeh.pdf

Wood, S. L. (2002). Future fantasies: A social change perspective of retailing in the 21 st century. Journal of Retailing, 78(1), 80. http://dx.doi.org/10.1016/S0022-4359(01)00069-0

Yulihasri, Islam, M. A., \& Ku Daud, K. (2011). Factors that Influence Customers' Buying Intention on Shopping Online. International Journal of Marketing Studies, 3(1), 128-139. http://dx.doi.org/10.5539/ijms.v3n1p128

Zhang, L., Tan, W., Xu, Y., \& Tan, G. (2012). Dimensions of Consumers' Perceived Risk and Their Influences on Online Consumers' Purchasing Behavior. Communications in Information Science and Management Engineering, 2(7), 8-14. http://dx.doi.org/10.1007/978-3-642-24823-8_1

Zulhuda, S. (July 19, 2009). E-Commerce and Consumer Protection in Malaysia. Trubute.

\section{Copyrights}

Copyright for this article is retained by the author (s), with first publication rights granted to the journal.

This is an open-access article distributed under the terms and conditions of the Creative Commons Attribution license (http://creativecommons.org/licenses/by/3.0/). 